\title{
Mapping of Soil Erosion Risk in the Diarha Watershed Using Rusle, RS and GIS
}

\author{
Ibrahima Thiaw ${ }^{1, *}$, Honoré Dacosta ${ }^{2}$ \\ ${ }^{1}$ Laboratory of Hydrology and Morphology, Cheikh Anta Diop University, Dakar, Senegal \\ ${ }^{2}$ Faculty of Arts and Social Sciences, Department of Geography, Cheikh Anta Diop University, Dakar, Senegal
}

Email address:

ibrahima4.thiaw@ucad.edu.sn (I. Thiaw),dacosta.honore@gmail.com (H. Dacosta)

${ }^{*}$ Corresponding author

\section{To cite this article:}

Ibrahima Thiaw, Honoré Dacosta. Mapping of Soil Erosion Risk in the Diarha Watershed Using Rusle, RS and GIS. American Journal of Remote Sensing. Vol. 5, No. 4, 2017, pp. 30-42. doi: 10.11648/j.ajrs.20170504.11

Received: December 19, 2017; Accepted: January 2, 2018; Published: January 20, 2018

\begin{abstract}
Mapping of erosive risks is a prerequisite in an erosion control approach. It makes it possible to locate the sectors most vulnerable to erosive processes. The establishment of the erosive risk map results from the spatialization of the Revised Universal Soil Loss Equation (Rusle). This equation is combined with Geographic Information Systems (GIS) and Remote Sensing (RS) techniques to estimate and map average rates of soil loss. If it is possible to significantly reduce soil water erosion through adapted farming techniques such as crop rotation, milling, banding and mulching, it is first necessary to target strong erosion requiring priority intervention. This study was conducted in the Diarha watershed and its sub-basins to assess potential soil losses and map the main factors involved in soil erosion processes. The results show that the erosive risks vary according to climatic and topographic gradients but also soil characteristics of the watershed. Potential soil losses vary between 0 and $1873 \mathrm{t} / \mathrm{ha} /$ year depending on the sector. The assessment yielded an average of $36.4 \mathrm{t} / \mathrm{ha} /$ year and a standard deviation of 105.3t/ha/year. Annual soil losses in the entire Diarha catchment area are estimated at 31882t/year; with a specific degradation of $42 \mathrm{t} / \mathrm{km}^{2} /$ year. The results will be compared to those of the Gambia watershed in Kedougou station which is contiguous to it.
\end{abstract}

Keywords: Diarha, GIS and RS, Rusle, Watershed

\section{Introduction}

Soil erosion is a complex phenomenon in which several factors can occur. In watersheds, the intensity of the kinetic energy of rain is the main erosive agent [1]. It gives the rain an ability to detach the land's particles. Thus, the detachment of the particles will be all the more considerable as the intensity of the rains is high. However, in bare or poorly permeable areas even low intensity rain can trigger runoff and cause splash erosion and sheet erosion. Rainfall efficiency is largely dependent on land use patterns, associated developments, and topographic status [2].

The Sudano-Guinean climate, the Precambrian basement formations, the differential of the upstream slopes downstream, the intensity and the seasonal, interannual and spatial irregularity of the rainfall [3], give the Diarha watershed an important sensitivity to erosive processes. Since 1968, the Diarha catchment has experienced an unprecedented drought, which has resulted in a decline in soil and water resources. Added to this is the development and intensification of lowland agriculture resulting from the abandonment of upland agriculture, the destruction of vegetation and overgrazing. More and more agricultural projects, such as those of SODEFITEX and PADAER, and uncontrolled mining spread over very fragile soils.

Soil loss can be estimated from in situ measurements or empirical formulas for universal adaptation. Sedimentological studies often require quite heavy financial means. However, the emergence of Geographic Information Systems and Remote Sensing offers new approaches for modeling water resources as well as processes for the transfer of sediments or pollutants. These are based on mathematical representations of fundamental hydro-climatic and erosive processes [4]. They are often applied to small geographical areas (agricultural plots, watersheds) such as the Soil and Water Assessment Tools model, [5].

If it is possible to significantly reduce soil water erosion 
through adapted farming techniques such as Crop Rotation, Milling, Banding and Mulching [6], it is first necessary to target strong erosion requiring priority intervention. RUSLE modeling (Revised Universal Soil Loss Equation), by Renard et al. [7], makes it possible to estimate the soil particles likely to be torn off and to map the zones most sensitive to water erosion. As a result, it is possible to locate areas of high erosion requiring priority intervention. The advantage of the RUSLE model lies in the fact that it takes into account the majority of the factors playing a preponderant role in the processes of soil water erosion, namely the erosivity of rainfall ( $\mathrm{R}$ factor), the length of the slope and its surface gradient (LS factor), soil erodibility (K factor), the effect of vegetation in presence (C factor), and anti-erosion cultural practices (P factor). According to this model, the damage of erosion comes primarily from the aggressiveness of tropical rains rather than a hypothetical fragility of tropical soils.

The purpose of this study is to map the main factors involved in soil erosion processes, as well as the vulnerability of the Diarha watershed at erosive risk. In addition, the estimation of erosion factors coupled with the mapping of areas vulnerable to soil erosion may be very useful in assessing the extent and degree of risk in order to implement conservation measures soil and water management plans.

\section{Study Area}

The Diarha watershed is a tributary of the left bank of the Gambia River. It extends between $12^{\circ} 15^{\prime}$ and $12^{\circ} 40^{\prime}$ North latitude and between $12^{\circ} 20^{\prime}$ and $13^{\circ}$ West longitude. It straddles two states: the Republic of Guinea Conakry in the
South represents $57 \%$ of the area of the basin, and the Republic of Senegal in the North, which occupies $43 \%$. The watershed lies entirely in the Birrimian basement formations, which gave rise, as a result of a process of physico-chemical alteration of the rocks, to soils with hydrogeological characteristics dominated by the impermeability of the superficial formations. With an area of $759.3 \mathrm{~km}^{2}$, the Diarha runs $45 \mathrm{~km}$ upstream downstream. It was born at the confluence of two tributaries (Niogola and Fangama) that originate at Fouta Djallon (Guinea Conakry), at about $576 \mathrm{~m}$ altitude.

The basin is controlled by a single hydrometric station that was commissioned in May 1975. This flow control station is located on the Kaldé-Salemata departmental road about 16.06 $\mathrm{km}$ from its confluence with the Gambia River in the locality of Lengueketo.

From a climatic point of view, the Diarha catchment straddles two climatic domains: the South-Sudanian domain in the North and the Guinean domain in the South. It is influenced by the West African monsoon, with an irregular and variable rainy season ( 7 to 8 months) and a short dry season (4 to 5 months). Rainfall varies according to a NorthSouth gradient, with $1136 \mathrm{~mm}$ in the North and $1344 \mathrm{~mm}$ in the South. The months of July, August and September represent $71 \%$ of the annual rainfall contributions.

With a Sudano-Guinean climate, average temperatures (Tm) of the Diarha catchment follow a bimodal evolution with a main peak in April $\left(32.8^{\circ} \mathrm{C}\right)$ and a secondary maximum in October $\left(27.7^{\circ} \mathrm{C}\right)$. The main minimum is observed in December $\left(25.3^{\circ} \mathrm{C}\right)$ and the secondary minimum in August $\left(26.5^{\circ} \mathrm{C}\right)$. The annual thermal amplitude is $13.5^{\circ}$.

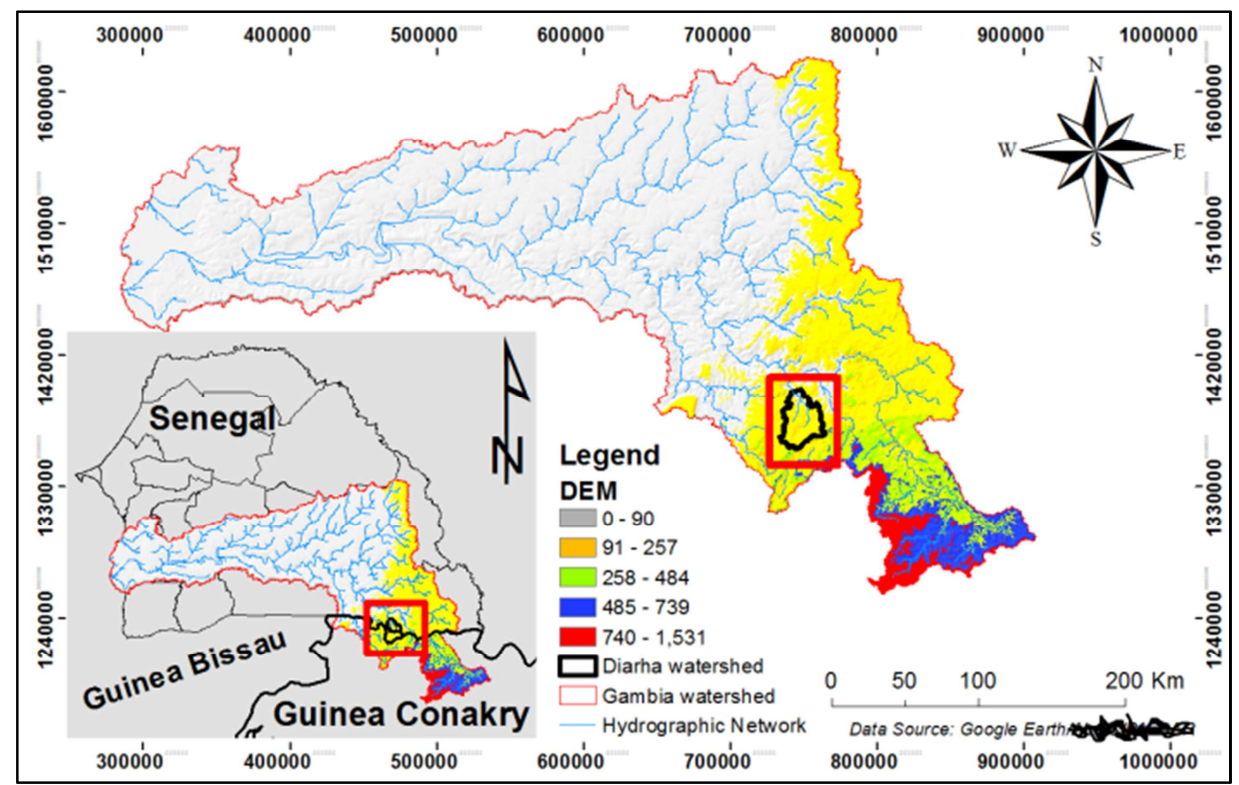

Figure 1. Location of the Diarha watershed in the Gambia River catchment area.

\section{Materials and Methods}

\subsection{Topographic Factor (LS)}

The LS factor has two elements: surface gradient $(\mathrm{S})$ and length (L) of slope. In the case of slopes slightly inclined erosion by splash effect and diffuse erosion are directly related to the kinetic energy of raindrops of rain [8]. Beyond a slope greater than $2 \%$, erosion experiences exponential growth [9], due to channel formation and growth, with the 
speed of runoff, diffuse erosion rates. The strong growth rate of erosion with the slope, then results mainly from the effect of the inclination on the speed of the runoff which can become sufficient to form ditches.

The slope length (L) and its slope gradient (S) were determined according to the procedure of Renard et al. [7]. For the factor (L), the landscape is divided into segments according to the inclination of each slope as shown below:

$$
L=\left(\frac{\lambda}{72.6}\right)^{m}
$$

where $(\mathrm{m})$ is the exponent of the slope length:

$$
[\mathrm{m}=\beta /(1+\beta)]
$$

$-\lambda$ is the slope length (in meters) and

$$
\begin{gathered}
\quad \beta=(\sin \theta / 0.0896) /\left[3(\sin \theta)^{0.8}+0.56\right] \\
\mathrm{S}=\text { Con }(\text { Tan }(" S l o p e " * 0.01745)<0.09,10.8 * \operatorname{Sin}(" S l o p e " * 0.01745)+0.03,16.8 * \operatorname{Sin}(" S l o p e " * 0.01745)-0.5)
\end{gathered}
$$

The procedure for calculating these parameters via GIS is primarily to correct SRTM errors by filling in its depressions with Arcgis Spatial Analyst Tools. Then, the direction and accumulation of flows in each resolution cell or pixel from the altimetric values of the Digital Terrain Model were determined, knowing that the water follows the path defined by the line of greatest slope. The accumulation of flows (flow-acc) was then used to determine the slope length (L). The second step was to calculate the slope using the Slope tool of Spatial Analyst Tools, to determine the exponent (m) and the factor $(\mathrm{S})$. The final step was to combine these two factors ( $\mathrm{L}$ and $\mathrm{S}$ ).

Several studies have shown that solid transports grow according to the slope, shape and length of the slope $[10 ; 11]$. These processes have an impact on the formation of gullies on the soil surface.

\subsection{Anti-Erosion Cultural Practices}

The support practice factor (P) in RUSLE is defined as the ratio of soil loss with a specific support practice to the corresponding loss with upslope and downslope tillage. $\mathrm{P}$ factor principally affect erosion by modifying the flow pattern or direction of surface runoff and by reducing the amount and rate of runoff [12].

In this study the $\mathrm{P}$ factor was estimated basing on slope system of the watershed (Table 1).

Table 1. Value of P factor (Ref Singh, 1994).

\begin{tabular}{ll}
\hline Land Slope $\%$ & P Value \\
\hline $1-2$ & 0.6 \\
$3-5$ & 0.5 \\
$6-8$ & 0.5 \\
$9-12$ & 0.6 \\
$13-16$ & 0.7 \\
$17-20$ & 0.8 \\
$21-25$ & 0.9 \\
$>25$ & 1 \\
\hline
\end{tabular}

in which: $\theta$ is the angle of the slope; and $\beta$ is the erosion rate of the gullies.

The gradient of slope (S) was calculated according to the equations of $\mathrm{McCool}$ et al. [9], as follows:

$$
\begin{gathered}
\mathrm{S}=(10.8 \times \sin \theta)+0.03 \text { for } \mathrm{S}<9 \% \text { and } \\
S=(16.8 \times \sin \theta)+0.50 \text { for } \mathrm{S} \geq 9 \%
\end{gathered}
$$

Integrated in a GIS these equations become:

$$
\begin{aligned}
& \mathrm{L}=\frac{\text { Power("Flow Acc"+(Cells),"m"+1)-Power("Flow Acc","m"+1) }}{\text { Power (Cells,"m" + 2) * Power }(22.13, " \mathrm{~m} ")} \\
& \beta=\frac{(\operatorname{Sin}(\text { "Slope" } * 0.01745) / 0.0896)}{(3 * \text { Power }(\operatorname{Sin}(\text { "Slope" } * 0.01745), 0.8)+0.56)} \\
& m=\frac{\beta}{(1+\beta)}
\end{aligned}
$$

The morphometric characteristics of the Diarha watershed and its sub-basins were determined using data from the Shuttle Radar Topographic Mission (SRTM 1 arc/second) for the National Aeronautics and Space Administration (NASA).

The processing of data from the SRTM satellite and the extraction of morphometric parameters were facilitated by the ArcGis 10.2 software, developed by the Institute for Research on Environmental Systems (ESRI).

\subsection{Soil Erodibility Analysis}

In this study, the soil map was extracted from the Harmonized World Soils Database [13]. Brown's texture triangle [14] and Stone and Hilborn's correspondence table [15] have made it possible to derive the soil erodibility ( $\mathrm{K}$ factor) from the texture. However, soil texture values are expressed in the US system, that is, tons/acre. They were therefore converted into the international system, and for this a factor of 0.1317 is multiplied by each value of $\mathrm{K}$ (Table 2).

Soil erodibility $(\mathrm{K})$ is a function of Organic Matter (OM) and soil texture, permeability and profile structure. It usually depends on the nature of the soil, the inclination of the slope and the density of the vegetation cover. It ranges from 0.70 for the most fragile soils to 0.01 for the most stable soils [16].

Table 2. Diarha' $K$ factor and Organic Matter (OM) values for different textures (Ref-HWSD).

\begin{tabular}{llllll}
\hline Sand\% & Silt\% & Clay\% & Organic Carbon\% & Organic Matter\% & K \\
\hline 75 & 13 & 12 & 0.7 & 1.204 & 0.05 \\
49 & 28 & 23 & 0.58 & 0.997 & 0.34 \\
69 & 18 & 13 & 0.46 & 0.791 & 0.14 \\
57 & 19 & 24 & 0.33 & 0.567 & 0.2 \\
57 & 19 & 24 & 0.33 & 0.567 & 0.2 \\
54 & 27 & 19 & 1.12 & 1.926 & 0.14 \\
54 & 27 & 19 & 1.12 & 1.926 & 0.14 \\
39 & 28 & 33 & 0.81 & 1.393 & 0.33 \\
\hline
\end{tabular}




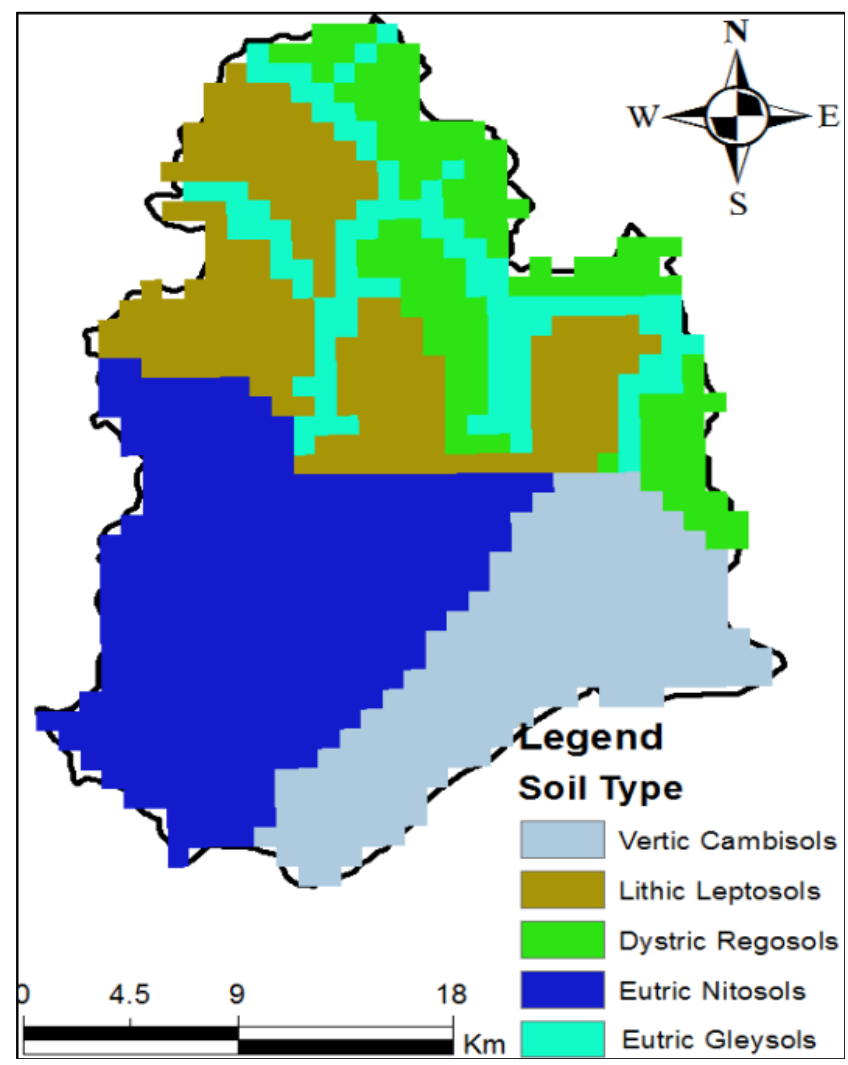

Figure 2. Mapping of the main soil types of the Diarha watershed.

\subsection{Rainfall Erosivity Analysis}

Soil erosion is highly dependent on the kinetic energy of water drops due to splash and runoff effects. Wischmeier [1], by correlating erosion, instantaneous intensity and kinetic energy of water drops, considers that soil erosion is directly proportional to the maximum rainfall intensity of 30 minutes
$\left(\mathrm{I}_{30} \mathrm{mn}\right)$ and total kinetic energy $(\mathrm{E})$. This relationship helps to evaluate the effect of rain on the soil. However, these types of meteorological data are very difficult to obtain and are not available in the study area.

In the absence of available data necessary for the estimation of the $\mathrm{R}$ factor, other authors have developed formulas allowing, from the monthly rainfall [17; 18], and annual $[19 ; 20]$, the calculation of this factor. Several studies carried out in West Africa on soil water erosion highlight a linear relationship between kinetic energy and rainfall. According to Roose [20], the relationship between the average annual aggressiveness index (R), and the mean annual rainfall $(\mathrm{P})$ is expressed in West Africa according to this equation:

$$
R=P \times 0.5+0.05
$$

The application of this equation requires homogeneous rainfall data over a period of at least ten years, and a good spatial distribution of rainfall stations. However, the heterogeneity of the measurement stations of the Diarha catchment does not allow a good calculation of the $\mathrm{R}$ factor; in which case a single value would be generalized to the whole basin. Thus, the climate data needed for this study were extracted from the Worldclim 2 database [21]. This database contains monthly average weather data from around the world for temperatures and precipitations from 1970 to 2000. The spatial resolution ranges from 30 seconds to 10 minutes.

To extract the climate data from the basin, we made a Clip of the Worldclim database with the basin villages file using the Arcgis' Spatial Analyst Sample tool; then spatialized the annual averages of each station by the interpolation technique of the Inverse Distance Weight (IDW) (Figure 3).

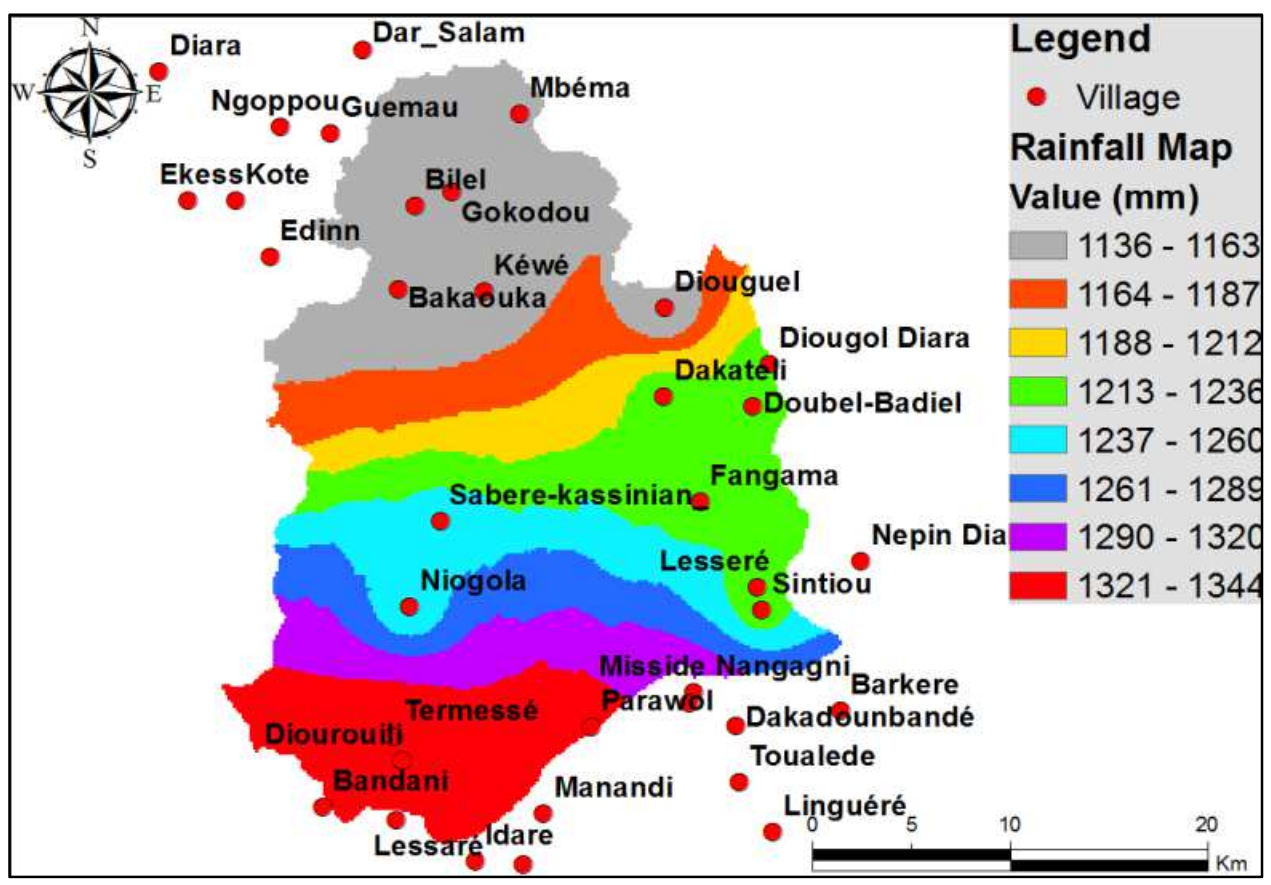

Figure 3. Spatial variation of rainfall in the Diarha Basin. 


\subsection{Cover Management Analysis}

The study of land use/land cover was based on the interpretation of Landsat OLI/TIRS satellite images (Table 3 ). To counter atmospheric effects on vegetation, surface reflectance was calculated using Envi software.
The classification of land use has been validated using Google Earth's very high spatial resolution images. Thus, five classes of land use have been identified: (1) Village, (2) Agricultural Area, (3) Open Forest, (4) Dense Forest, (5) Gallery Forest, (6) Bare Soil and (7) Water.

Table 3. Description of satellite images data.

\begin{tabular}{lll}
\hline Data type & Source & Description \\
\hline DEM & Earth Explorer & CARTO DEM (SRTM 1 arc/s) \\
Landsat OLI/TIRS & Earth Explorer & High resolution image (30 m); Path 202, Row 051; Date November 08, 2017 \\
Soil data & HWSD/Version 1.1 & Harmonized Soil Map of the World based on the soil textures \\
Climate data & Worldclim.org/Version 2 & Average worldwide monthly rainfall data (1970-2000), Resolution 30 seconds \\
\hline
\end{tabular}

The Rusle equation uses five sub-factors to calculate the $\mathrm{C}$ factor: soil management; soil cover by plant canopy; soil cover by crop residues; roughness of soil surface; and soil moisture [7]. However, the assessment of each sub-factor is difficult because of the many possible combinations, and the time spent with data acquisition and analysis [22]. In this study, the $\mathrm{C}$ factor was determined from the rescaling NDVI, according to the method proposed by Durigon et al. [23]:

$$
\mathrm{Cr}=[(-\mathrm{NDVI}+1 / 2)]
$$

This method is a prerequisite for Rusle $\mathrm{C}$ factor and is recommended for use in tropical regions [24].

Cover management factor $(\mathrm{C})$ varies from near zero for a well-protected land cover to 1 for barren areas [25]. Hence, the impact of this factor on soil erosion is not much important when the land use-land cover of the watershed area comprises highest percentage of forest and plantation crops.

\subsection{Soil Loss Modeling}

The Rusle model of Renard et al. [7] is an improvement of the Universal Soil Loss Equation (USLE) of Wischmeier and Smith [1]. It is combined with techniques and methods of Geographic Information Systems and Remote Sensing to estimate and map the average rate of soil loss. However, only the sheet erosion processes are taken into account by this model.

Rusle is an empirical and quantitative model that combines factors with a strong influence on soil water erosion, namely the kinetic energy of intense rainfall ( $\mathrm{R}$ factor), the physicochemical properties of soils ( $\mathrm{K}$ factor), terrain characteristics (LS factor), vegetation cover (C factor) and anti-erosion practices ( $\mathrm{P}$ factor). It is obtained from this formula:

$$
A=R \times K \times L S \times C \times P
$$

where $\mathrm{A}$ is the soil loss per unit area, $\mathrm{R}$ is the Rain-erosivity factor, $\mathrm{C}$ is the Cropping and Management factor, $\mathrm{K}$ is the soil erodibility factor, LS is the slope length and steepness factor and $\mathrm{P}$ is the conservation practice factor.

In present study, calculation of Soil Erosion using RUSLE based on Sub-watersheds level. The Diarha watershed has nine sub watersheds (Figure 4).

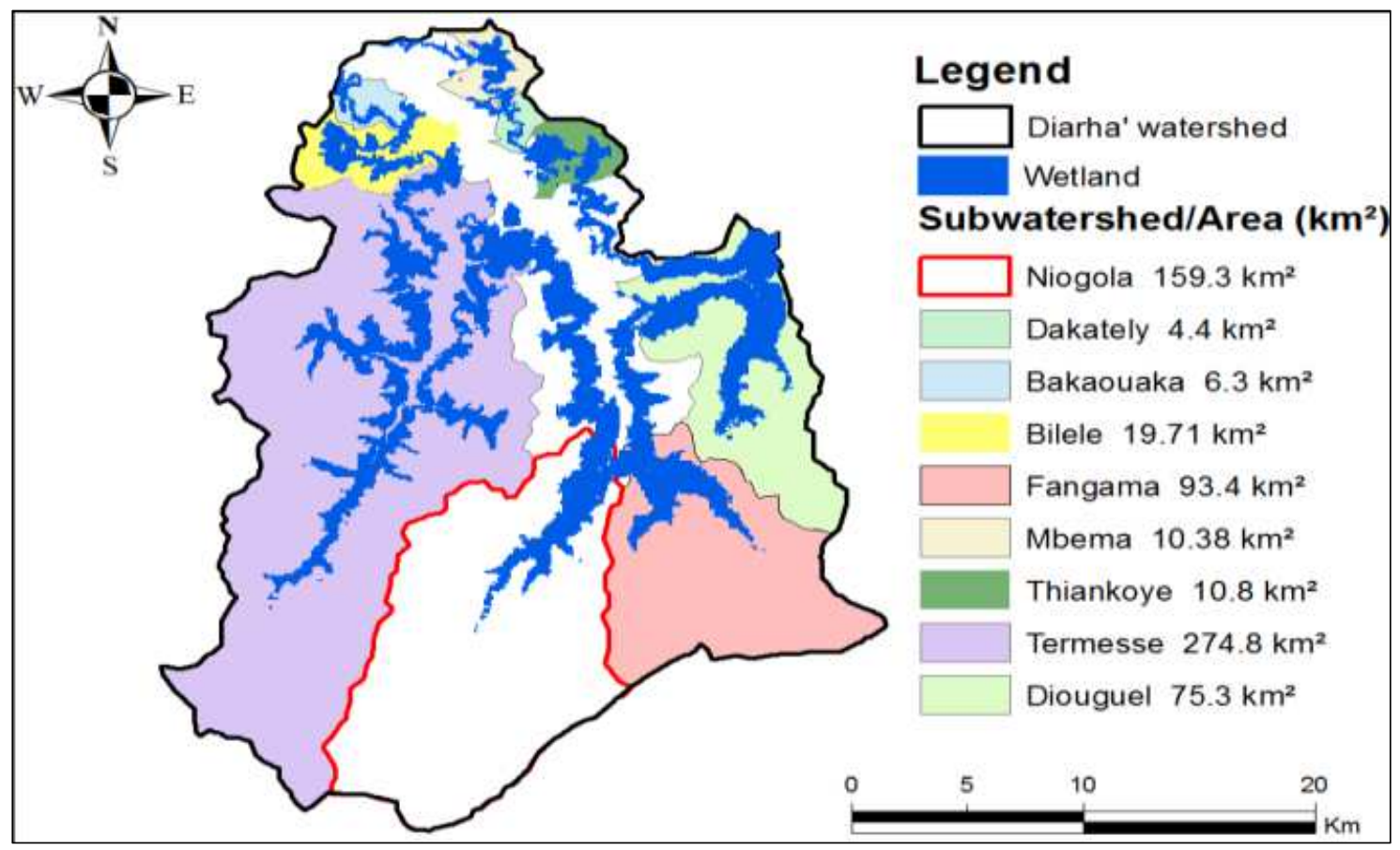

Figure 4. Sub-watersheds Map. 
The synthesis of the general methodological approach presented in Figure 5 explains the use of the Revised Universal Soil Loss Equation (RUSLE) in a GIS environment. All Rusle model's factors were processed and obtained using ArcGIS 10.2 and ENVI 5 software. The product of these factors resulted in annual soil loss throughout the Diarha Basin.

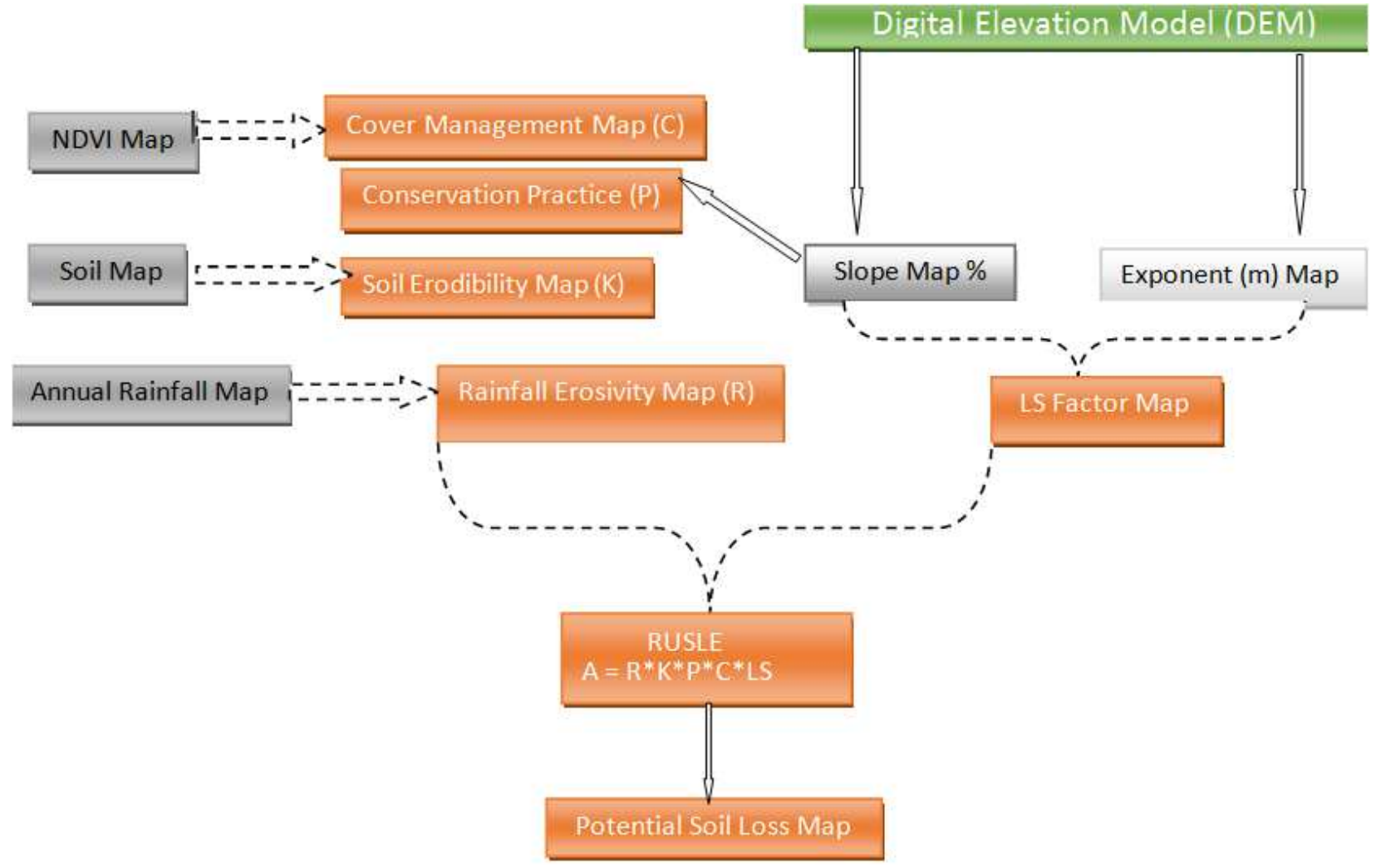

Figure 5. Synthesis of the methodological approach used.

\section{Results and Discussion}

\subsection{Topographic Factor (LS)}

The slopes of the basin follow the topographic gradient of the watershed. Slope classes $0-2 ; 3-4$ and 5-8 scattered throughout the basin, occupy more than $86 \%$ of the basin area. Slope class 23-43, very localized, notably along the Northern part of the Fouta Djallon foothills and to the North-west (Bassari Mountains), occupies only 3.8\% of the basin (Figure 6).

The following figures (Figures 7-15) show the results of the various parameters involved in the calculation of the topographic factor LS. They highlight a contrast between the different models of the Diarha watershed. At the Center and downstream, the weak slopes of the Diarha watershed are not very sensitive to erosion processes, whereas upstream and to the Northwest, the steep reliefs reveal a greater sensitivity to erosive processes.

The topographic factor LS shows that $93.8 \%$ of the basin surface is in class 0 to 2.16 , and $6.2 \%$ in that of 2.17 to 30.5 , which reveals the heterogeneous nature of the topography of the Diarha catchment. The lowest values (0.03 to 0.37$)$ are attributed to the streambed and the highest (7.76 to 30.47) to the Northern foothills of the Fouta Djallon, the Bassaris Mountains and the steepest slopes.

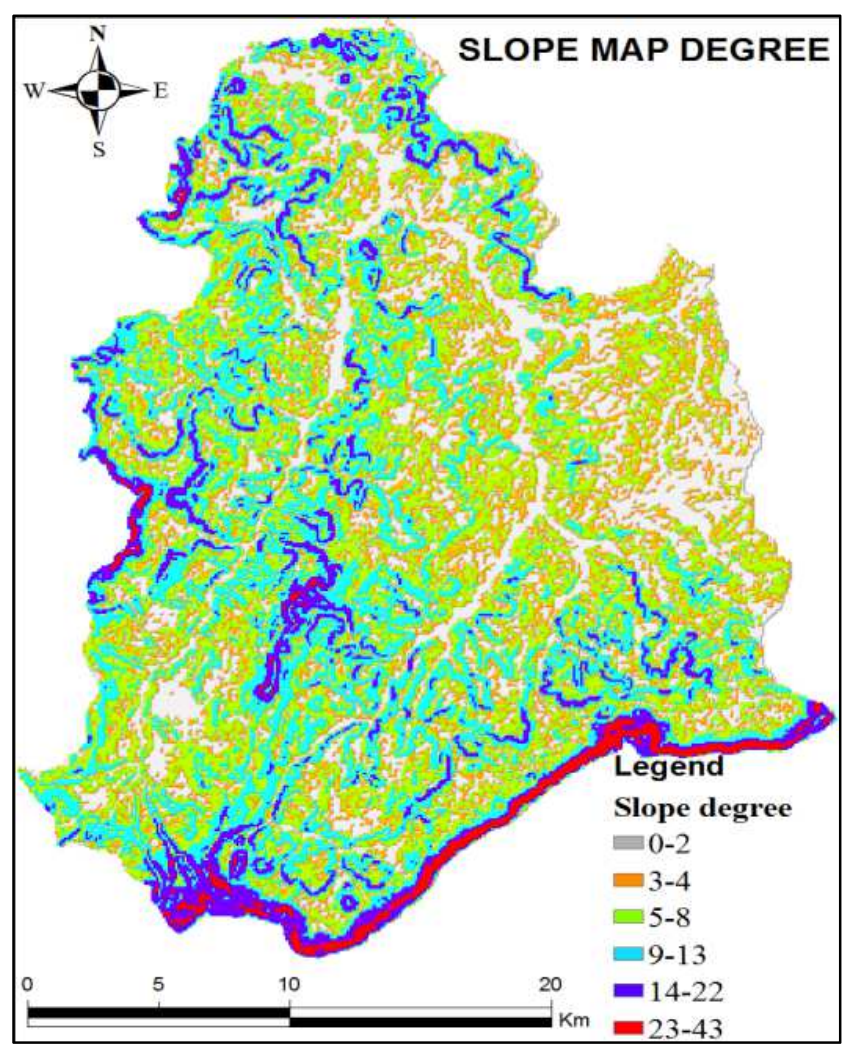

Figure 6. Diarha watershed' Slope System (Degree). 


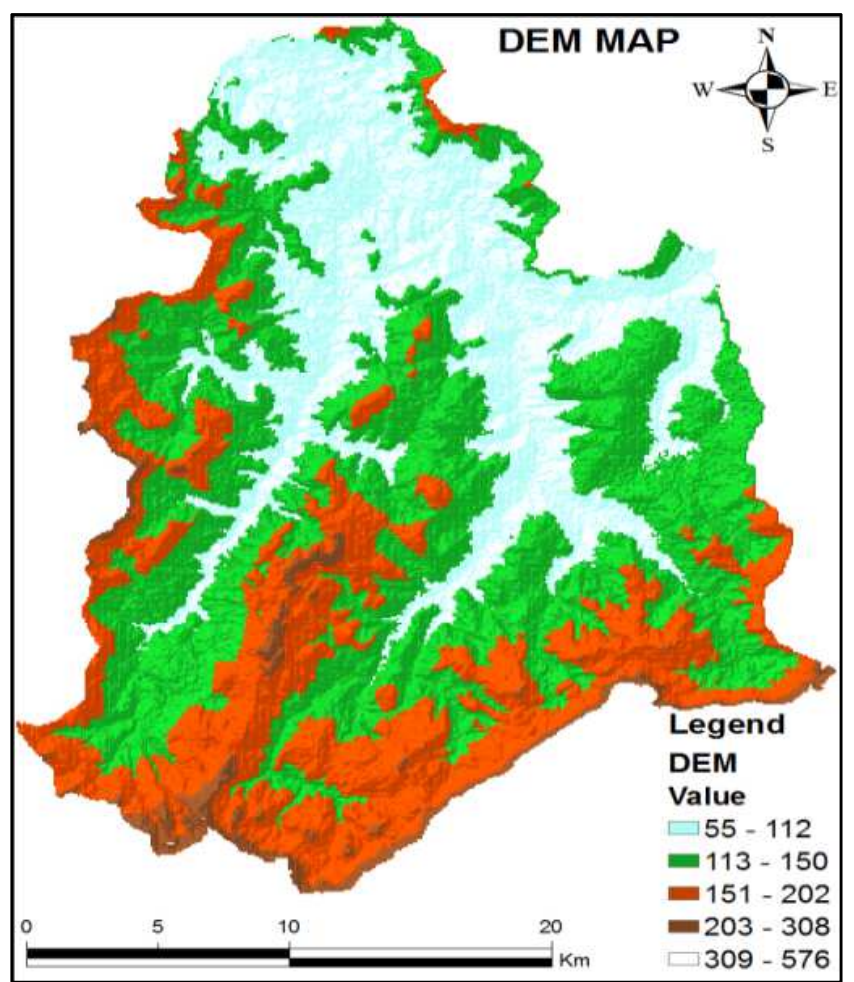

Figure 7. Digital Elevation Model Map.

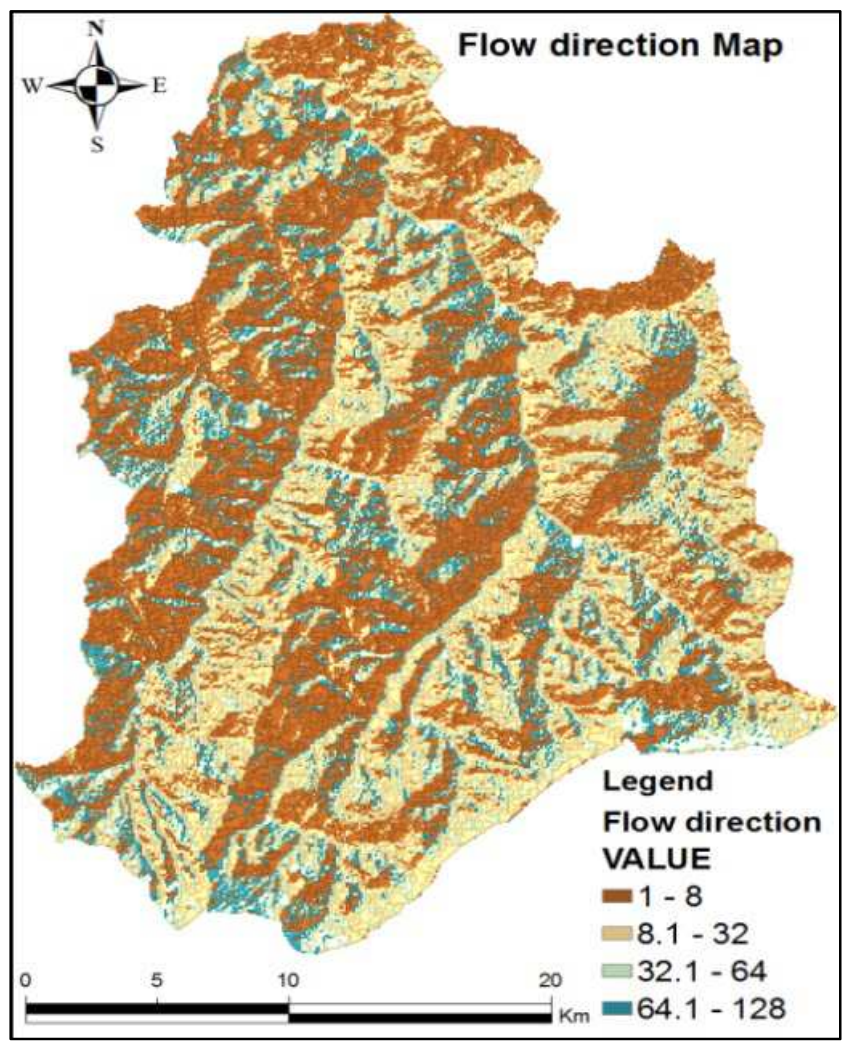

Figure 8. Flow Direction Map.

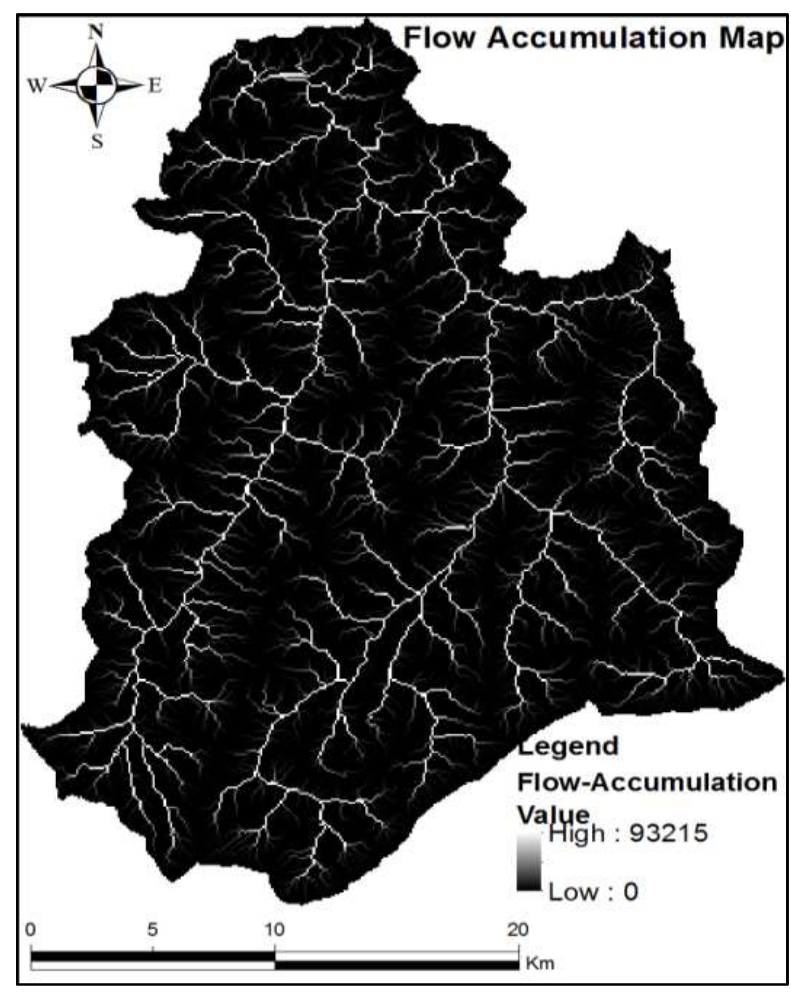

Figure 9. Flow Accumulation Map.

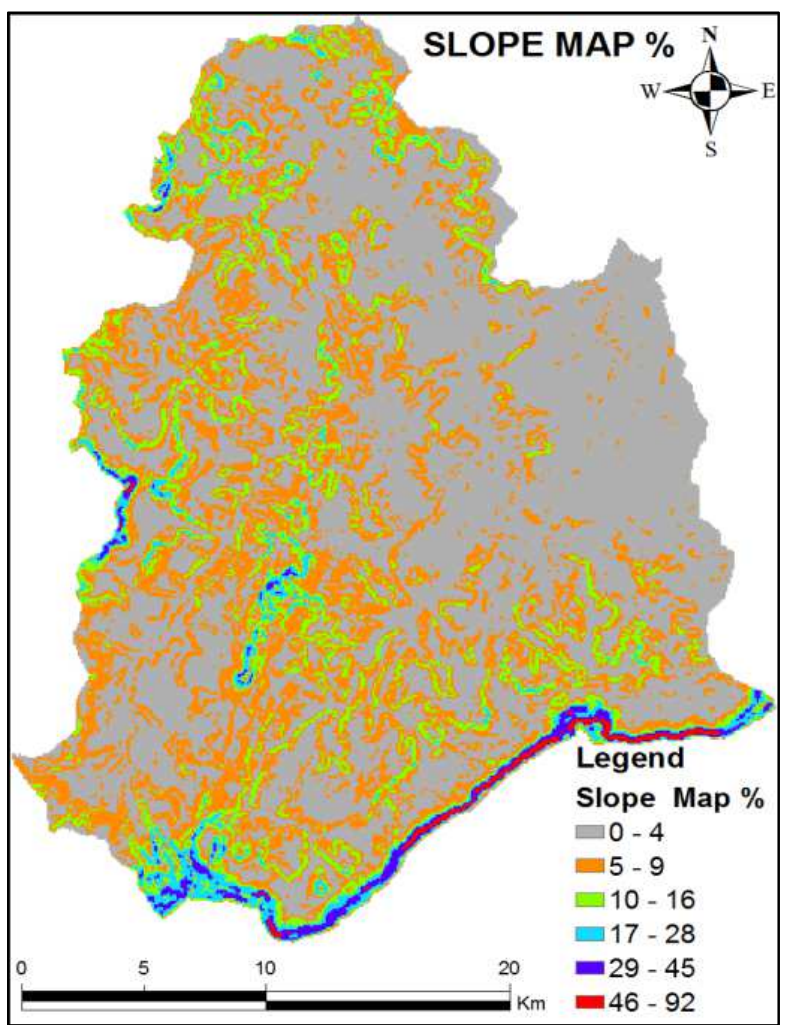

Figure 10. Slope Map (Percentage). 


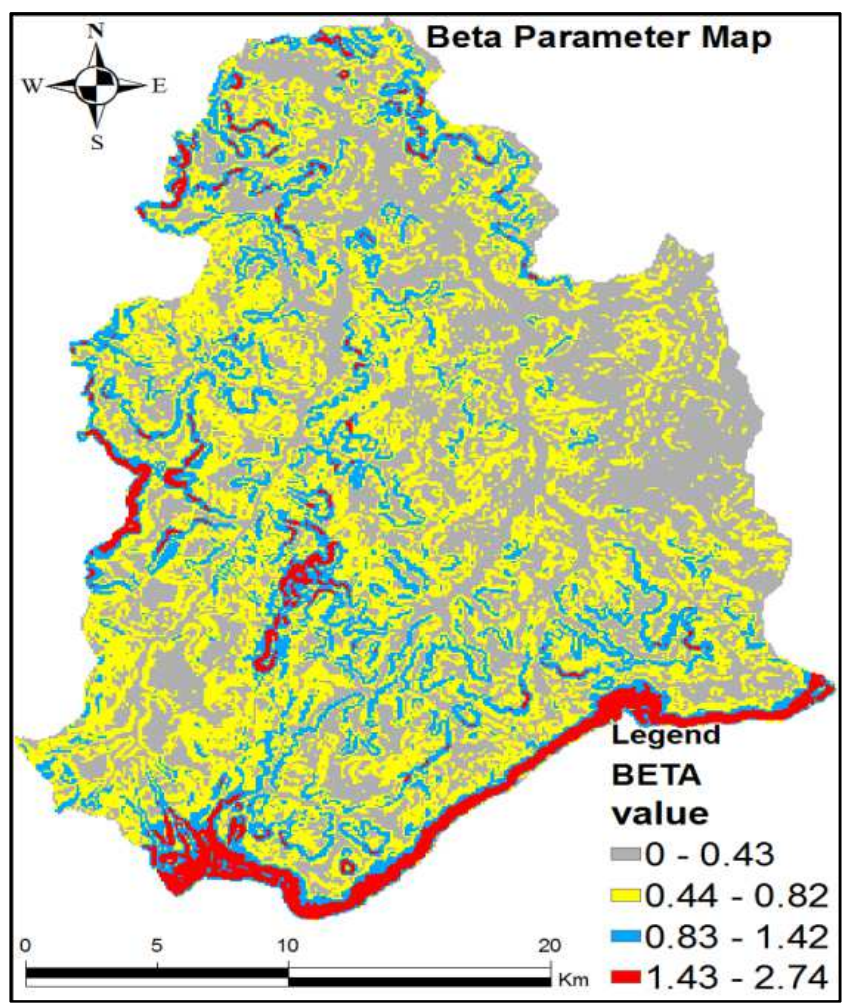

Figure 11. Beta Parameter Map.

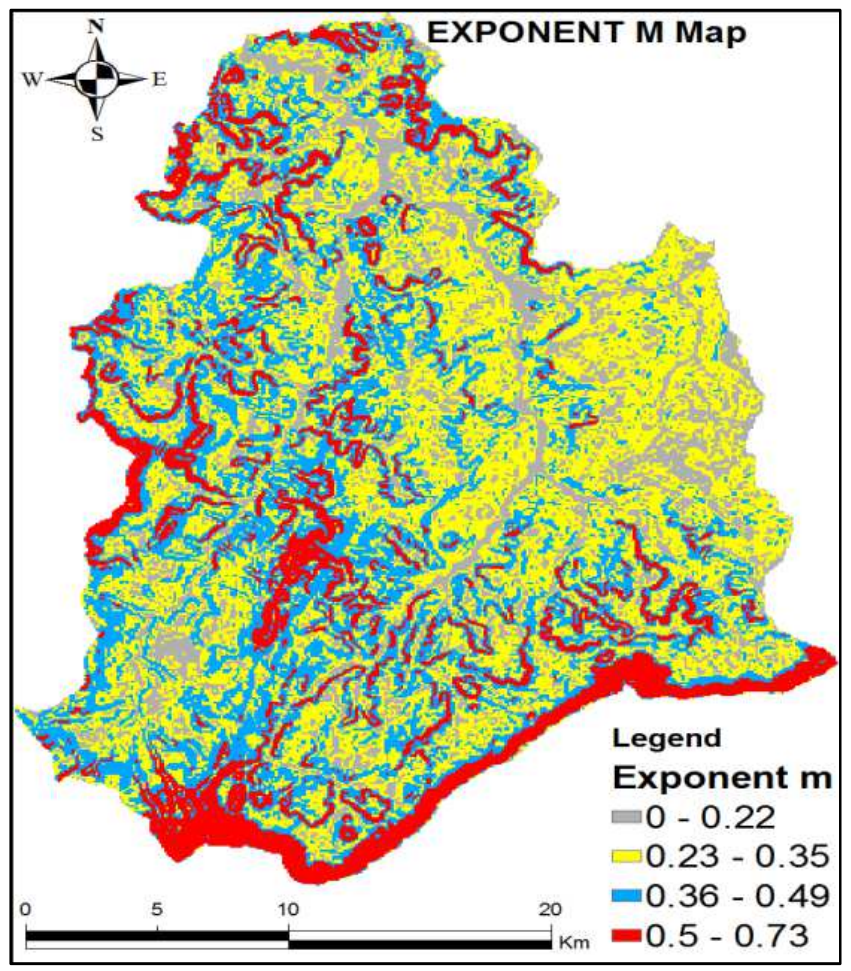

Figure 12. Exponent m Map.

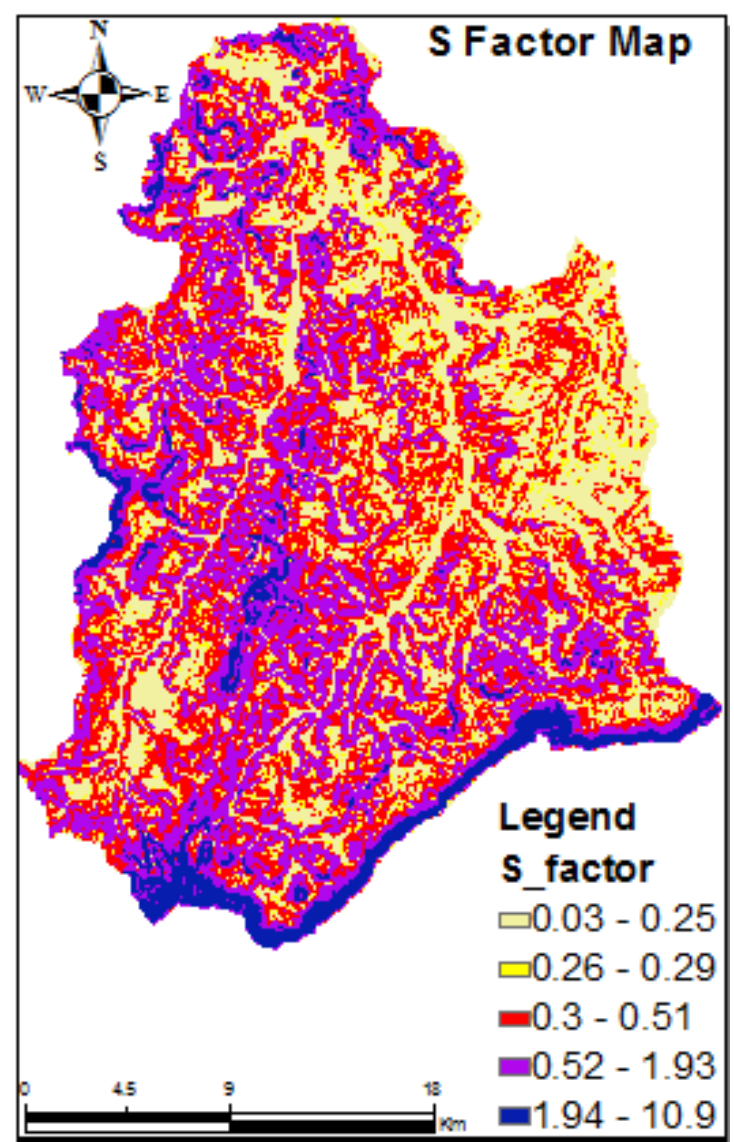

Figure 13. S Factor Map.

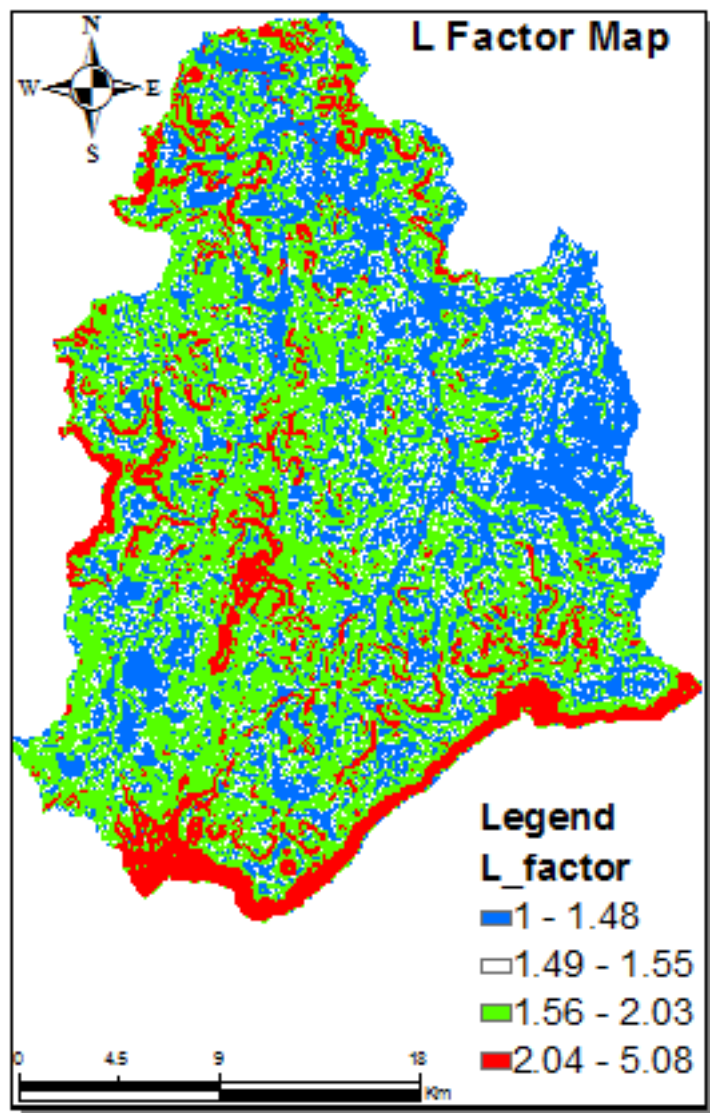

Figure 14. L Factor Map. 


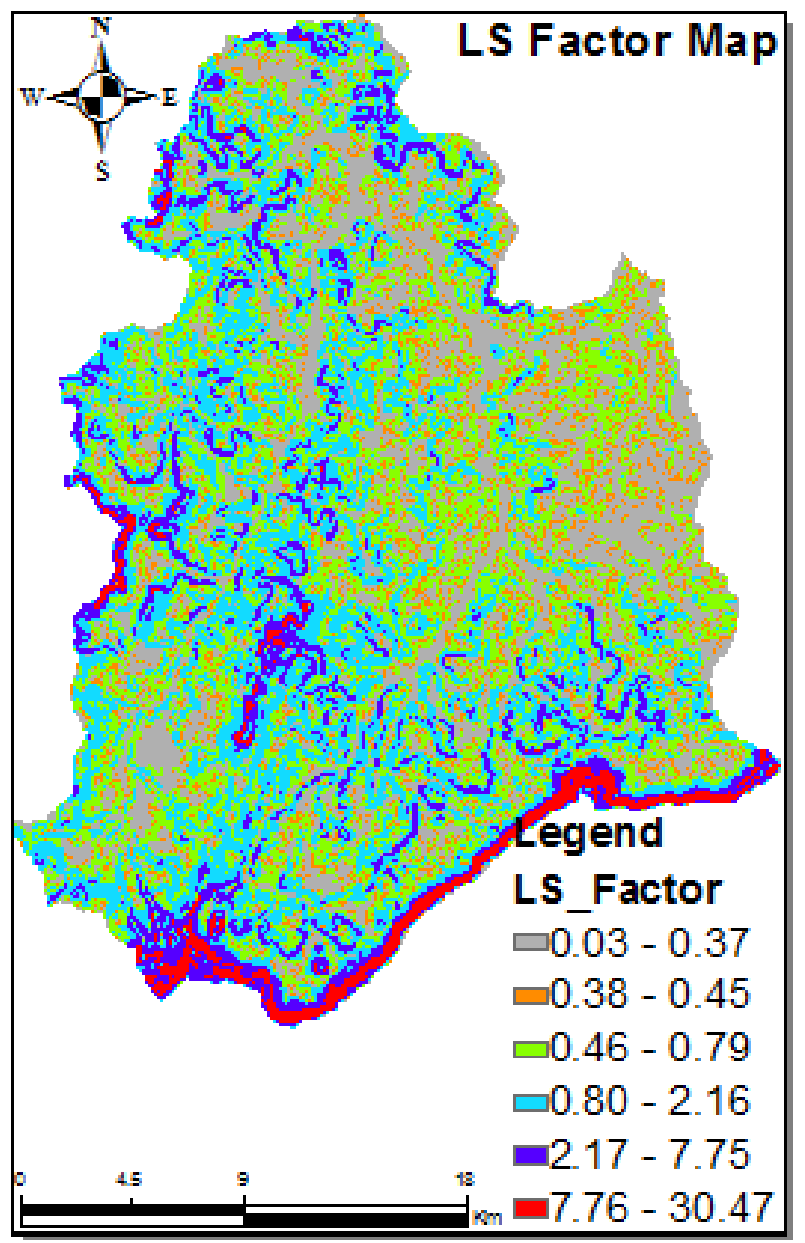

\subsection{Climatic Erosivity (R Factor)}

The spatial distribution of the rainfall erosivity factor $(\mathrm{R})$ shows that the Diarha watershed is subject to increasing rainfall erosion on a North-South gradient, with a slight increase from East to West.

The analysis of the $\mathrm{R}$ factor map shows that the rainfall erosivity varies between 568 and $672 \mathrm{MJ} . \mathrm{mm} / \mathrm{ha}$.h.yr, with an average of 620MJ.mm/ha.h.yr. These results allow deducing that the Diarha basin is subjected to a high erosive power.

The lowest erosivity classes (568 to $582 \mathrm{MJ} . \mathrm{mm} /$ ha.h.yr) are localities in the sectors of Mbéma, Bilèle, Kéwé, Diouguel and Bakaouka, North of the Diarha basin. They occupy $27 \%$ of the basin area. In this part of the basin, the average annual rainfall varies between 1000 and $1163 \mathrm{~mm}$.

In the Guinean part of the basin, with an intense rainfall (greater than $1200 \mathrm{~mm}$ ), the risk of erosivity of the rains is very severe (600 to $672 \mathrm{MJ} . \mathrm{mm} / \mathrm{ha}$.h.yr).

Table 4. Classes of annual Rainfall erosivity ( $R$ factor).

\begin{tabular}{llll}
\hline Classes & Erosivity R & Area & Percent\% \\
\hline $568-582$ & Slight & 204 & 27 \\
$583-593$ & Low & 58 & 8 \\
$594-606$ & Moderate & 55 & 7 \\
$607-618$ & High & 130 & 17 \\
$619-630$ & Very High & 84 & 11 \\
$631-644$ & Severe & 62 & 8 \\
$645-672$ & Very Severe & 168 & 22 \\
Total & & 759 & 100 \\
\hline
\end{tabular}

Figure 15. LS Factor Map.

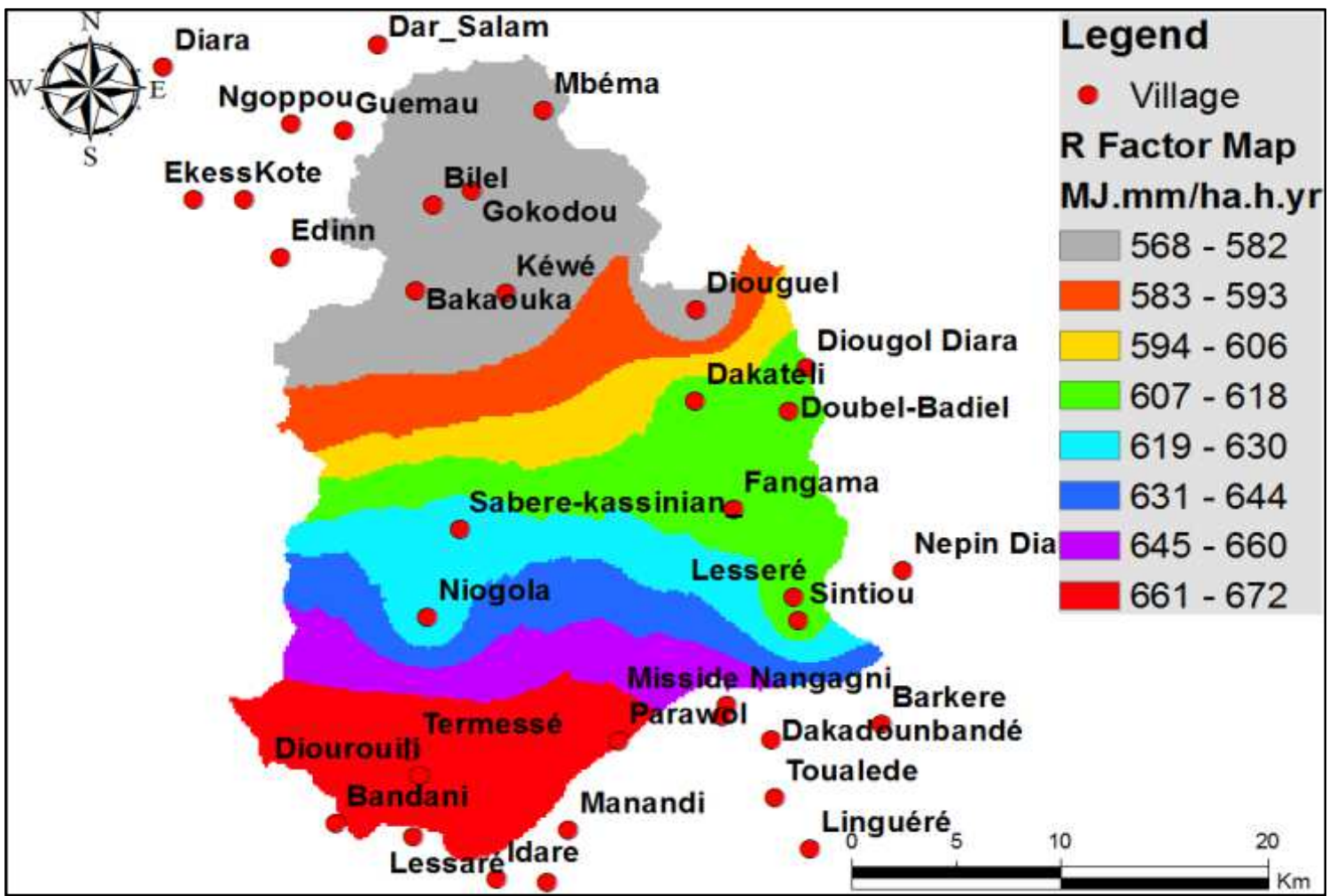

Figure 16. Map of climatic erosivity ( $R$ factor). 


\subsection{Soil Erodibility (K Factor)}

The results obtained for soil erodibility ( $\mathrm{K}$ factor) at the scale of the Diarha catchment ranged from 0.05 to 0.14 t.ha.h/ha/MJ.mm for the most resistant soils (Cambisols); from 0.15 to 0.20 t.ha.h/ha /MJ.mm for soils the resistant means (Leptosols and Regosols) and from 0.21 to 0.34 t.ha.h/ha/MJ.mm for the most erodible soils (Nithosols and Gleysols).

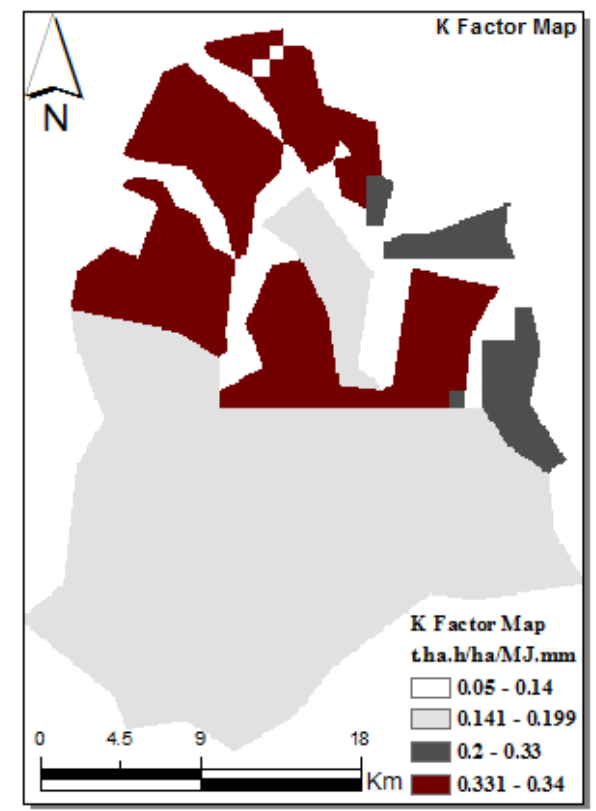

Figure 17. K Factor Map.

\subsection{Anti-Erosion Cultural Practices (P Factor)}

In this study, the values of the weaker anti-erosive practices ( $\mathrm{P}$ factor) correspond to those of the weak to moderate slopes.

The P-factor varies between 0.66 and 1 for the steeper areas, generally located in the South and North-west of the Diarha catchment area.

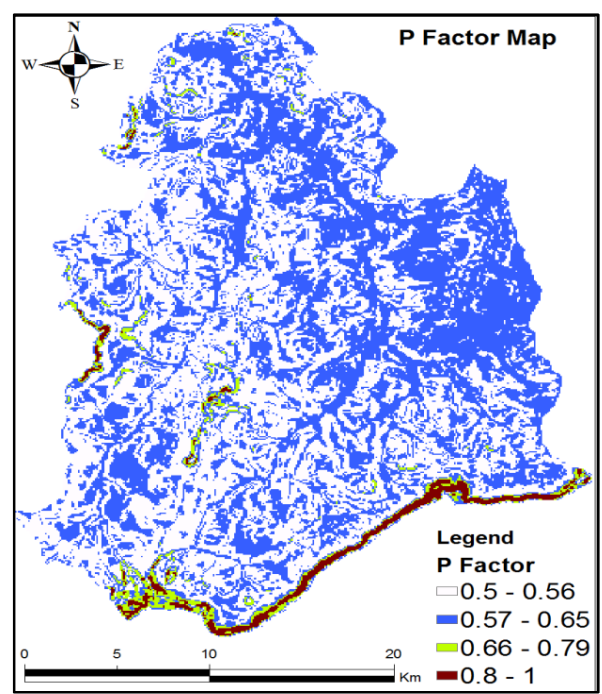

Figure 18. P Factor Map.

\subsection{Cover Management C Factor}

Vegetation plays a decisive role in the hydrology of a watercourse. Its installation and maintenance are related to lithology and climate. However, its hydrological efficiency depends on a fundamental notion in surface hydrology: that of the vegetal cover. The latter acts on the water cycle by its aerial biomass, which intercepts a part of the precipitation whose intensity depends on the density of the plant cover; and by its root system which, according to its importance, also maintains and furnishes the banks of watercourses and plays a decisive role of protection against erosion of runoff and support of low-water flows.

In this study, the influence of vegetation cover on soil water erosion was analyzed from factor C (Figure 19), which is derived from the NDVI (Figure 20). The vegetation cover is considered as the second factor (after the topography) to control the risk of water erosion of soils. Soil loss decreases with the density of vegetation cover [20].

Analysis of the $\mathrm{C}$-factor map reveals that the highest values are for water, bare soil and farmland, with the lowest values being for plant cover.

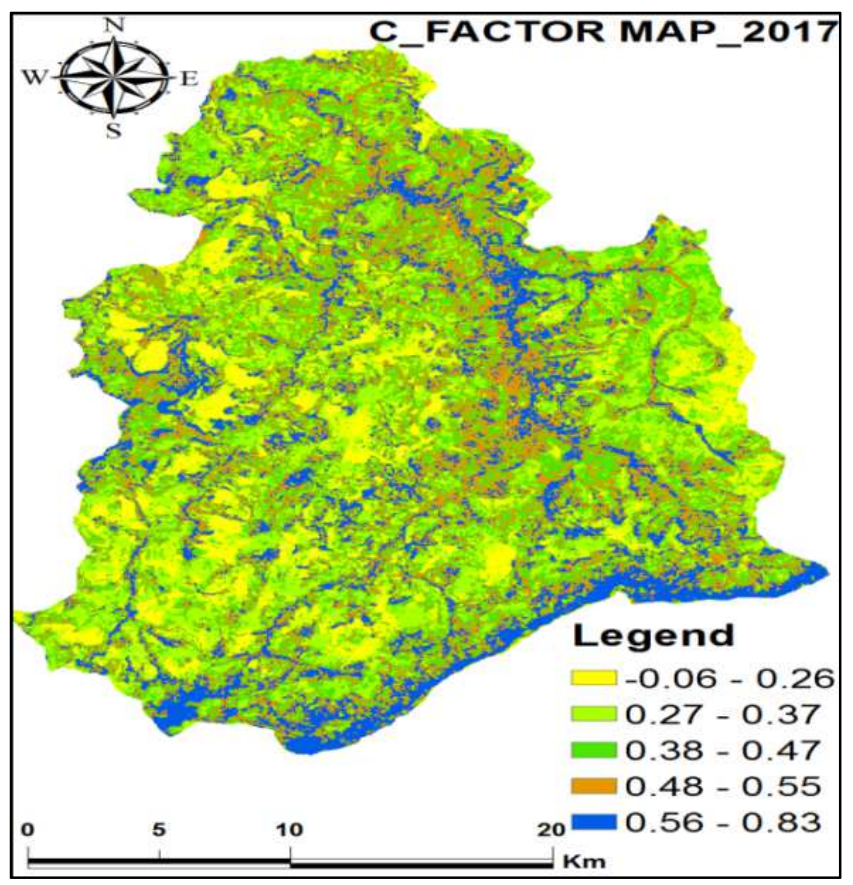

Figure 19. Cover Management C Factor Map.

Analysis of the land use map (Figure 21) and Table 5 shows that vegetation cover alone accounts for more than $50 \%$ of the Diarha catchment area. Three types of vegetation cover have been identified. It is in order of importance: (1) the Forest Gallery which borders the banks of the downstream basin occupies $19 \%$ of the area of the basin; (2) Dense forest, mainly located in the South and East, occupies $17 \%$ of the basin and (3) the Open Forest represents $16 \%$ of the catchment area. The forest cover index, which is the ratio of total forest area to catchment area, is 0.52 . 


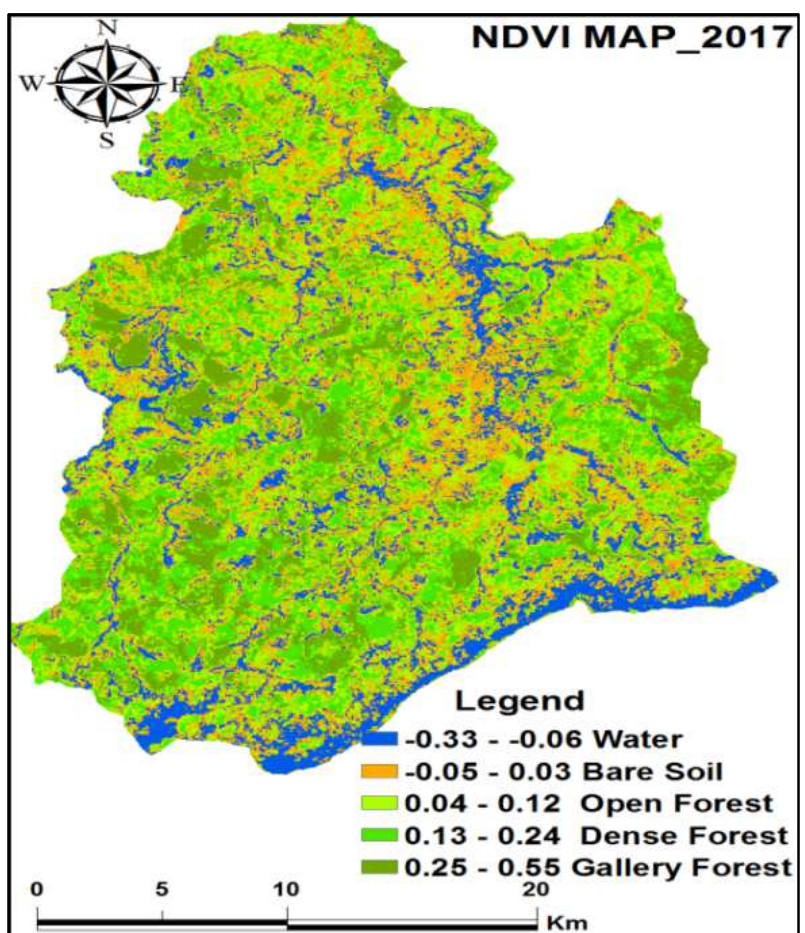

Figure 20. NDVI Map.

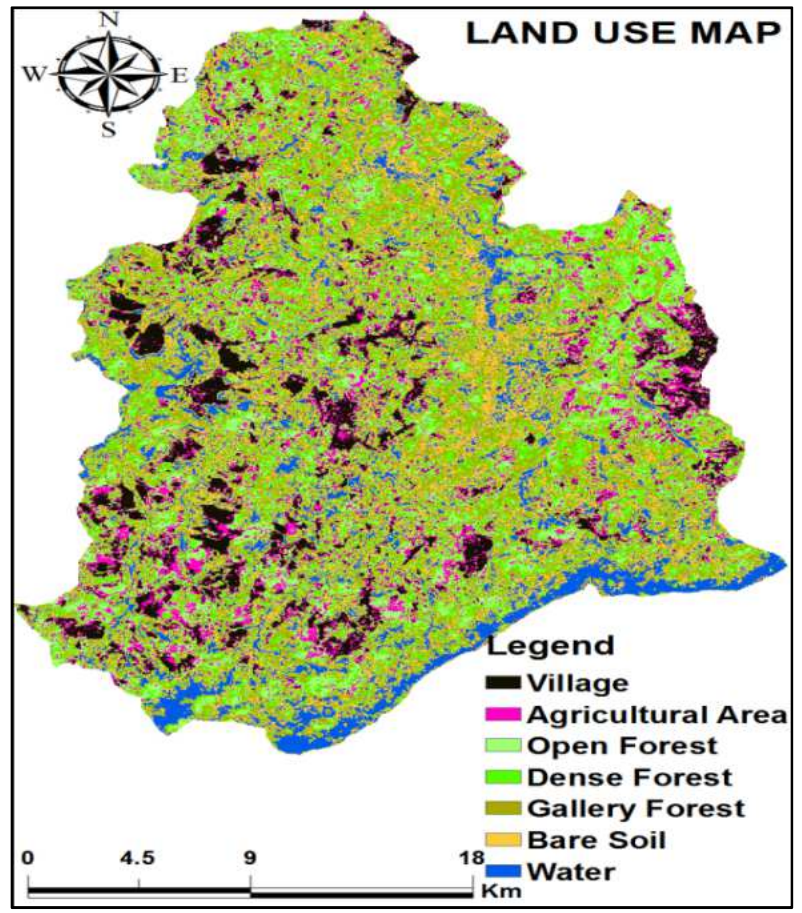

Figure 21. Land use Map.

Table 5. Statistics of Land use classes.

\begin{tabular}{lll}
\hline Land Use & Area $\left(\mathbf{k m}^{\mathbf{2}}\right)$ & Area Percent\% \\
\hline Village & 67.9 & 9 \\
Agricultural Area & 85.6 & 11 \\
Open Forest & 125.0 & 16 \\
Dense Forest & 131.9 & 17 \\
Gallery Forest & 140.6 & 19 \\
Bare Soil & 133.6 & 18 \\
Water & 74.7 & 10 \\
Total & 759.3 & 100 \\
\hline
\end{tabular}

\subsection{Potential Annual Soil Losses}

The erosive risk map shows a strong spatial heterogeneity of erosion rates. They vary between 0 and $1873 \mathrm{t} / \mathrm{ha} / \mathrm{yr}$ depending on the sector (Figure 22). The assessment yielded an average of $36.4 \mathrm{t} / \mathrm{ha} / \mathrm{yr}$ and a standard deviation of 105.3t/ha/yr. However, despite their heterogeneity, these values show a spatial structure defined by topo-landscape location. The hillsides of the basin suffer the highest rates of erosion; mean values are observed at the upstream portions of the slopes and at the lowest values at the summit ridges, in the alluvial valleys and in the downstream concavities. Otherwise, alluvial valleys, unlike steep slopes and ridges, are sedimentation zones and not erosion zones [7]. The erosive risk map should therefore provide negative erosion values in these areas. This is due to the fact that the Rusle modeling does not take into account the transport/sedimentation processes by the drainage network. Areas of sedimentary deposits are often characterized by low risk of sediment detachment in the erosive risk map [26].

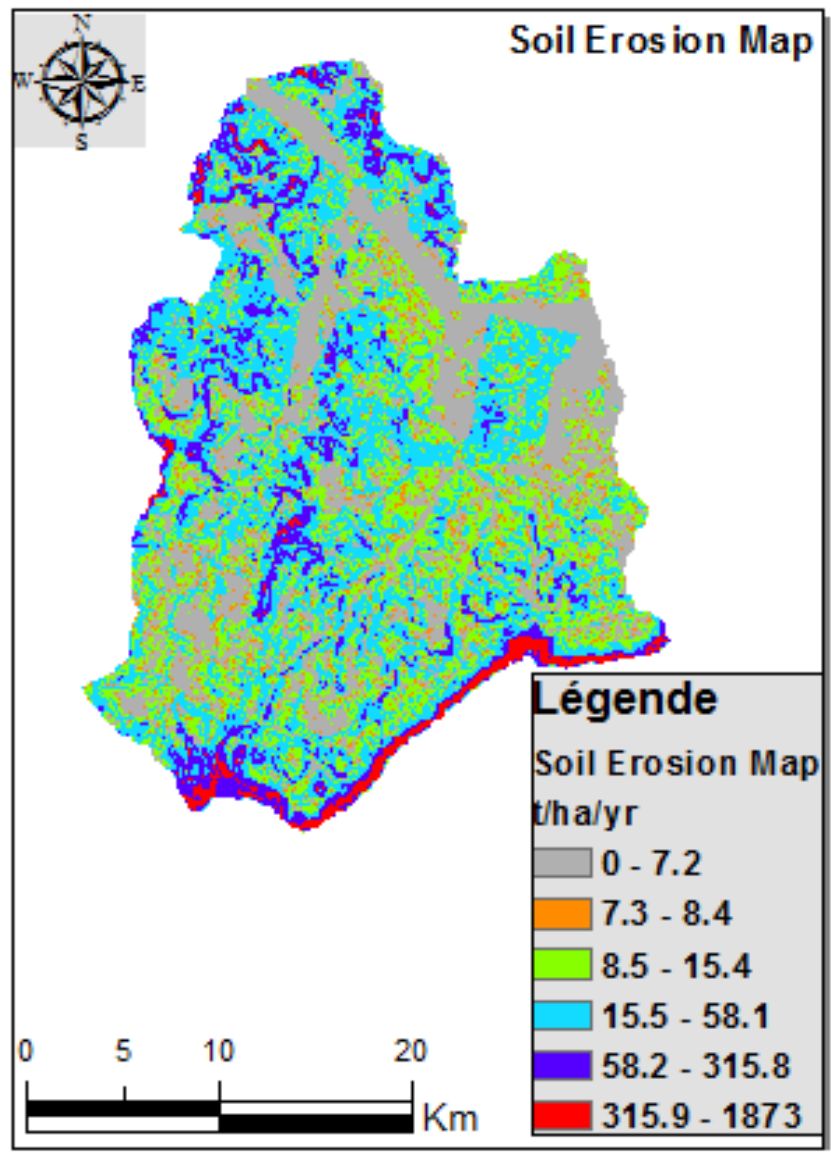

Figure 22. Potential Soil Loss Map.

The analysis in Table 6 reveals that $24 \%$ of the catchment area has a very low risk of erosion ( 0 to $7 \mathrm{t} / \mathrm{ha} / \mathrm{yr}$ ). This part of the basin, occupied by the alluvial valleys, is protected by the forest gallery which runs along the banks of the Diarha watershed from upstream to downstream. It occupies about $19 \%$ of the basin area and more than $35 \%$ of the vegetation cover. Classes from 7 to $15 \mathrm{t} / \mathrm{ha} / \mathrm{yr}$ present a low to moderate 
erosive risk. They occupy about $31 \%$ of the basin area. Erosion problems are very marginal in these areas due to the presence of much localized control mounds. While, the steeper areas are strongly subject to erosion: erosion rates vary between 58 and $1873 \mathrm{t} / \mathrm{ha} / \mathrm{yr}$.

Table 6. Classes and Statistics of Potential Soil losses.

\begin{tabular}{llll}
\hline Classes (t/ha/year) & Area $\left(\mathbf{K m}^{\mathbf{2}}\right)$ & Percent $\%$ & Erosivity Risk \\
\hline $0-7$ & 180 & 24 & Slight \\
$7-8$ & 57 & 8 & Low \\
$8-15$ & 174 & 23 & Moderate \\
$15-58$ & 258 & 34 & High \\
$58-316$ & 74 & 10 & Very High \\
$316-1873$ & 16 & 2 & Severe \\
Total & 759 & 100 & \\
\hline
\end{tabular}

The sub-basins of the Guinean part of the Diarha basin (Termessé, Fangama, Diouguel and Niogola) are more sensitive to soil erosion: erosion rates vary between 3000 and $13298 \mathrm{t} /$ year. As for those of the Senegalese part (Bilèle, Mbéma, Dakately, Bakaouka and Tiankoye) the average annual erosion rates vary between 200 and 955t/year (Table 7). Annual soil losses in the entire Diarha catchment area are estimated at 31882t/year; with a specific degradation of $42 \mathrm{t} / \mathrm{km}^{2} /$ year.

The results obtained show that the factors causing water erosion in the Diarha catchment area (rainfall intensity, soil characteristics; the slope length and its slope gradient) are the most influential factors in the increase in erosive potential.

Table 7. Potential Soil Loss per Sub-watershed.

\begin{tabular}{lll}
\hline Sub-watershed & Soil Loss & Specific Erosion \\
\hline & t/year & t/km $\mathbf{k m}^{\mathbf{y}} \mathbf{\text { year }}$ \\
\hline Niogola & 7873 & 49.4 \\
Termessé & 13298 & 48.4 \\
Fangama & 4561 & 49.0 \\
Diouguel & 3680 & 48.9 \\
Tiankoye & 502 & 46.5 \\
Bakaouka & 316 & 50.2 \\
Dakately & 207 & 47.0 \\
Mbéma & 490 & 47.1 \\
Bilèle & 955 & 48.5 \\
\hline
\end{tabular}

\section{Conclusion}

The objectives of this study were to map the main factors involved in soil erosion processes, as well as the vulnerability of the Diarha watershed to erosive risk. Adaptation of the Rusle model has identified areas most affected by land degradation, and the model can easily be applied to the entire Gambia watershed where measured solid flow data are available from 1979 to 1984 for the Gouloumbou station, and for the years 1974 and 1986 at the Kedougou station. According to Lerique [27] the average of the mechanical erosion obtained in the Gambia watershed at the Gouloumbou station is about $250.000 \mathrm{t} / \mathrm{year}$. At the Kedougou station it varies between 125/130.000t/year [28]. The erosive risk mapping method is, despite its limitations, a new management tool allowing managers to better target their priority intervention strategies.

\section{References}

[1] WISCHMEIER W. H. AND SMITH D. D. (1978). Predicting rainfall erosion losses - a guide for conservation planning. U.S. Department of Agriculture, Agriculture Handbook, Washington.

[2] FOTSING, 1993. Erosion of cultivated land and proposals for conservatory soil management in Bamileke country (West Cameroon), House of Remote Sensing, ORSTOM Laboratory 500, rue J. F. Breton, 34093, Montpellier France, http://horizon.documentation.ird.fr/exldoc/pleins_textes/cahiers/PTP/10009100. PDF.

[3] IBRAHIMA THIAW. Rainfall Variability and Water Supplies in the Diarha Watershed (Tributary of Gambia River). Hydrology. Vol. 5. No. 4, 2017, pp. 41-57. doi:10.11648/j.hyd.20170504.11.

[4] JAH, M. K. AND R. C. PAUDEL, 2010, «Erosion Predictions by Empirical Models in a Mountainous Watershed», Journal of Spatial Hydrology, vol. 10, $\mathrm{n}^{\circ} .1,14 \mathrm{p}$.

[5] ARNOLD, J. G., J. R. WILLIAMS, R. SRINIVASAN, K. W. KING ET R. H. GIGGS, 1995, SWAT Soil and Water assessment Tool: draft user manual, US department of Agriculture, Agriculture Service, Temple, TX.

[6] ROOSE, E., 1967. 10 years of measuring erosion and runoff in Senegal, Tropical Agronomy, Extract No 2 February 1967ORSTOM.

[7] RENARD K. G., G. R. FOSTER, G. A. WEESIES, D. K MCCOOL AND D. C. YODER (1997). Predicting Soil Erosion by Water: A Guide to Conservation Planning with the Revised Universal Soil Loss Equation (RUSLE), Agricultural Handbook No. 703, US Department of Agriculture, Washington DC.

[8] ROOSE, E., 1994. Introduction to the conservative management of water, biomass and soil fertility, FAO, Soil, Bulletin, 70p.http://horizon.documentation.ird.fr/exldoc/pleins_textes/divers11-03/41504.pdf.

[9] MCCOOL D, BROWN L, FOSTER G, MUTCHLER C AND MEYER L (1987). «Revised Slope steepness factor for the Universal Soil Loss Equation». Trans. Am. Soc. Ag. Eng. 30 p. 1387-1396.

[10] HUDSON, N. W., 1973, Soil conservation, Batsford, London, $320 \mathrm{p}$.

[11] MATI, B. M., R. P. C. MORGAN, F. N. GICHUKI, J. N. QUINTON, T. R. BREWER ET H. P. LINIGER, 2000, « Assessment of erosion hazard with the USLE and GIS: A case study of the Upper EwasoNg'iro North basin of Kenya » International Journal of Applied Earth Observation and Geoinformation, vol. 2, $\mathrm{n}^{\circ}$. 2, pp. 78-86.

[12] RENARD K. G AND G. R FOSTER 1983. Soil Conservation: Principles of erosion by water. In H. E Dregne and W. O Willis, eds. Dryland Agriculture pp. 155-176. Agronomy Monogr. 23, Am. Soc. Agron., Crop Sci. Soc. Am., and Soil sci. Soc. Am. Madison, Wisconsin.

[13] FAO/IIASA/ISRIC/ISS-CAS/JRC, 2009. Harmonized World Soil Database (version 1.1). FAO, Rome, Italy and IIASA, Laxenburg, Austria. 
[14] BROWN, R. B., 2003, Soil Texture, Soil and Water Science Department, Florida Cooperative Extension Service, Institute of Food and Agricultural Sciences, University of Florida, Fact Sheet SL29, 8 p.

[15] STONE, R. P. ET D. HILLBORN, 2000, Universal Soil Loss Equation, Ontario, Canada, Ontario Ministry of Agriculture and Food (OMAFRA), http://www.giser.be/wpcontent/uploads/2012/05/USLE-infosCanada.pdf.

[16] EL GAROUANI, A., H. CHEN, L. LEWIS, A. TRIBACK ET M. ABAHROUR, 2008, "Mapping of land use and net erosion from satellite images and IDRISI GIS in North-East Morocco", Remote sensing, vol. 8, $\mathrm{n}^{\circ}$ 3, p. 193201 , http://www.teledetection.net/upload/TELEDETECTION/pdf/V ol8No3_193_201.pdf.

[17] ARNOLDUS H. M. 1980. An approximation of the rainfall factor in the Universal Soil Loss Equation. In Assessments of Erosion, de Boodts M, Gabriels D (Eds). John Wiley and Sons Ltd, Chichester 127-132.

[18] OLIVEIRA JR, R. C., MEDINA, B. F. 1990. The erosivity of rainfall in Manaus (AM). Rev. Bras. Solo 14, 235-239.

[19] RENARD, K. G. AND FREIMUND, J. R. 1994. Using Monthly Precipitation Data to Estimate the $R$ factor in the Revised USLE. J. Hydrol. 157: 287-306.

[20] ROOSE, E., 1977, " Application of the Universal Soil Loss Equation of Wischmeier and Smith in West Africa ", Soil Conservation Society of America, Ankeny, Iowa, pp. 50-71, $\mathrm{http}: / /$ horizon.documentation.ird.fr/exldoc/pleins_textes/pleins_textes_5/b_fdi_08-09/09135.pdf.

[21] FICK, S. E AND R. J. HIJMANS, 2017. Wordclim 2: New 1 $\mathrm{km}$ spatial resolution climate surfaces for global land areas. International Journal of Climatology.
[22] SCHONBRODT, S.; SAUMER, P.; BEHRENS, T.; SEEBER, C.; SCHOLTEN, T., 2010. Assessing the USLE crop and management factor $\mathrm{C}$ for soil erosion modeling in a large, mountainous watershed in Central China. Journal of Earth Science, v.21, p.835-845, 2010. DOI: $10.1007 / \mathrm{s} 12583-010$ 0135-8.

[23] DURIGON, V. L.; CARVALHO, D. F.; ANTUNES, M. A. H.; OLIVEIRA, P. T. S.; FERNANDES, M. M, 2014. NDVI time series for monitoring RUSLE cover management factor in a tropical watershed. International Journal of Remote Sensing, v.35, p.441-453. DOI: 10.1080/01431161.2013.871081.

[24] CARVALHO D. F, DURIGON V. L, ANTUNES M. A. H, ALMEIDA W. S, AND OLIVEIRA P. T. S. Predicting soil erosion using Rusle and NDVI time series from TM Landsat 5; Pesq. agropec. bras., Brasília, v.49, n.3, p.215-224, mar.2014; DOI:10.1590/S0100-204X2014000300008.

[25] GANASRI, B. P., RAMESH, H., Assessment of soil erosion by RUSLE model using remote sensing and GIS - A case study of Nethravathi Basin, Geoscience Frontiers (2015), http://dx.doi.org/10.1016/j.gsf.2015.10.007.

[26] MORSCHEL J. AND FOX D. A method of mapping erosive risk: Application to the hills of Terrefort, Lauragais. M@ ppemonde $76(2004,4)$ http://mappemonde.mgm.fr/num4/articles/art04404.html.

[27] LERIQUE J., 1975. Solid suspended transports in the Gambia at Kedougou and Gouloumbou stations. Results of the 1974 campaign. ORSTOM report, Dakar, multigr., 11p.

[28] BAMBA S. B., 1987. Assessment of water and matter in the Upper Guinean Basin of the Gambia River. UCAD, doctoral, thesis. http://horizon.documentation.ird.fr/exldoc/pleins_textes/divers16-09/24301.pdf. 